\title{
盛土形状をパラメータとした カルバート縦断方向の動的遠心模型実験
}

\author{
宮崎 祐輔 1 ・澤村 康生 ${ }^{2}$ 岸田 $\quad$ 潔 $^{3}$ ・木村 亮 4 \\ 1学生会員 京都大学博士後期課程 工学研究科社会基盤工学専攻 ( \\ E-mail: miyazaki.yusuke.73x@st.kyoto-u.ac.jp \\ 2正会員 京都大学助教 工学研究科社会基盤工学専攻 ( $7615-8540$ 京都市西京区京都大学桂) \\ E-mail: sawamura.yasuo.6c@kyoto-u.ac.jp \\ 3 正会員 京都大学教授 工学研究科都市社会工学専攻 ( $7615-8540$ 京都市西京区京都大学桂) \\ E-mail: kishida.kiyoshi.3r@kyoto-u.ac.jp \\ 4正会員 京都大学教授 工学研究科社会基盤工学専攻 ( $7615-8540$ 京都市西京区京都大学桂) \\ E-mail: kimura.makoto.8r@kyoto-u.ac.jp
}

\begin{abstract}
ヒンジ式プレキャストアーチカルバートは，2011年に発生した東日本大震災により，供用性を損なう大 きな被災を初めて経験した．被災状況から，アーチ部材の損傷がカルバート縦断方向に規則的に並ぶとい った一方向に強い地震動を受けたような損傷が確認されており，土被りが小さい領域や坑口部で損傷が集 中している，そこで本研究では，ヒンジ式アーチカルバートを含む盛土模型に対し，盛土形状に注目した 動的遠心模型実験を実施した。 その結果, カルバートの土被りが小さい場合, 最も盛土の拘束効果が小さ くなる坑口部で, カルバートの応答が大きく増幅し周辺地盤の応答を卓越することを確認した. さらに, カルバートの土被りが大きい場合, 盛土の拘束効果が増加することで, カルバートは周辺地盤に追従的な 応答を示すことを確認した。
\end{abstract}

Key Words : precast arch culvert, culvert-longitudinal direction, patterns of earth covert, soil-culvert interaction, dynamic centrifuge test

\section{1. はじめに}

ヒンジ式プレキャストアーチカルバート (図-1参照)は, 本体断面を分割し，主要部材をプレキャスト製品とする ことで高い品質管理や工期の短縮を可能としたカルバー トである．断面の分割位置に応じて，さらに2ヒンジ式1) と3ヒンジ式少の大きく二種類のタイプに分けられるが (図-2), いずれの工法においても，分割位置に設けたヒ ンジ機能により, 部材の変形をある程度許容することで, 盛土からの地盤反力を積極的に引出し，安定化する構造 である. すなわち, 周辺地盤の変形をある程度許容し, 地盤反力をアーチに伝達する軸力に転換するため, 剛性 ボックスカルバートに比べて，部材厚を薄くしながら大 断面あるいは大土被りでの施工が可能である.

しかし，同構造物の地震時挙動はヒンジ構造により複 雑化し，明確な而震性評価手法はない，同構造物の而震 性を議論する際には，地震動の伝播方向とカルバートの 設置方向を関連付けて検討される，地震動の方向と道路
盛土の延長方向が平行である場合をカルバート横断方向, 直角である場合をカルバート縱断方向とする (図-1参照).

ヒンジ式アーチカルバートの耐震性は，ヒンジ部の逸 脱が構造全体の崩壊につながるため, 設計断面であるカ ルバート横断方向について主として検討されてきた ${ }^{3) ~ 8) . ~}$ 澤村ら ${ }^{9}$, Sawamura, et al. ${ }^{7}$ は, 実物の 1/5 スケールの3 3 ヒ ンジ式アーチカルバートに対して，大型振動台を用いて， 強震動によるヒンジ式アーチカルバートの限界状態及び

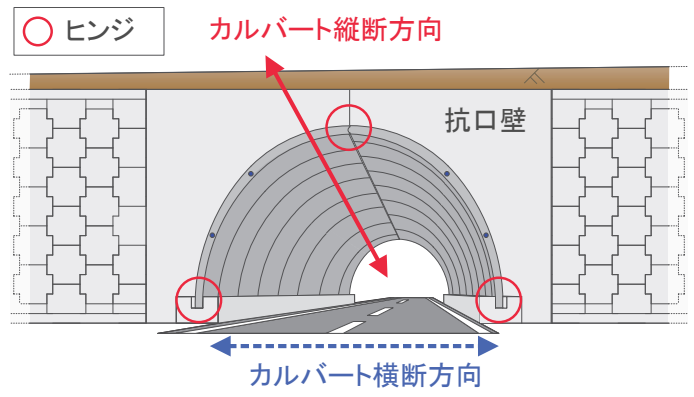

図-1３ヒンジ式プレキャストアーチカルバートを含む盛土 


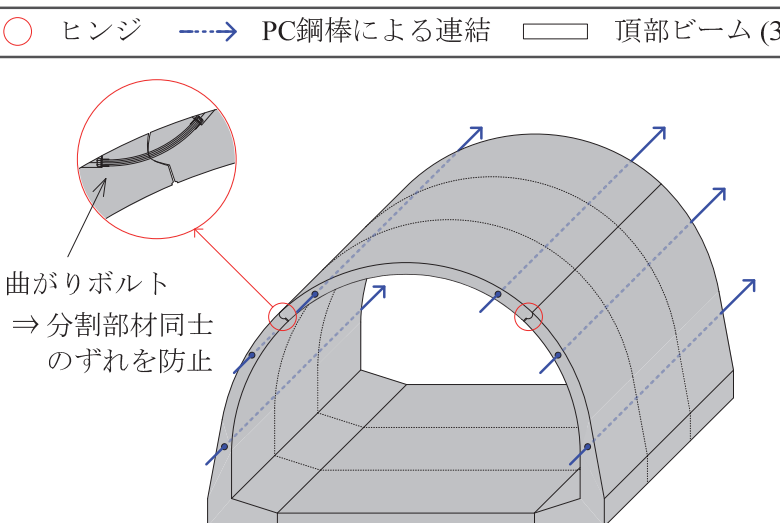

(a) 2ヒンジ式

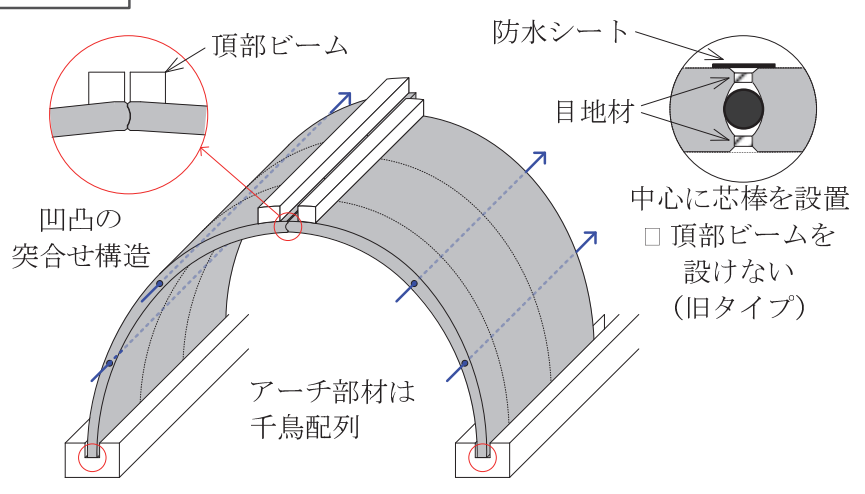

(b) 3ヒンジ式

図-2 代表的なヒンジ式アーチカルバート1),2)

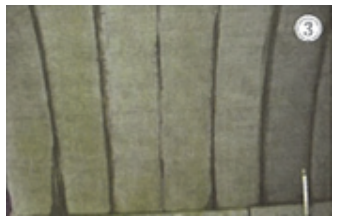

(a) アーチ部材の漏水

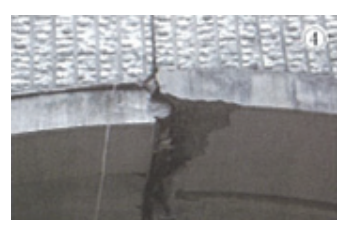

(c) 頂部ヒンジの損傷

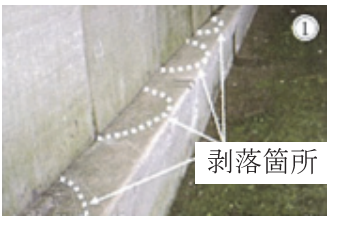

(b) 基礎コンクリートの損傷

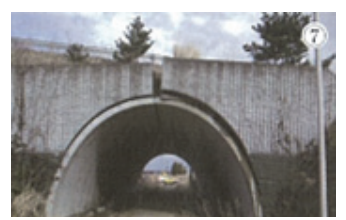

(d) 坑口壁の損傷

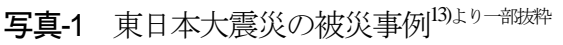

損傷進展過程を確認した。その結果，1/5 スケールの 3 ヒンジ式アーチカルバートは，せん断ひずみ 7 \%を越え る大きな変形を受けても，部材の終局に至る前にヒンジ 部が逸脱しないことが実験的に確認され，カルバート横 断方向に高い耐震性を有することが示された.

一方，カルバート縦断方向については，盛土被害の多 くがその方向に生じる9にもかかわらず，坑口部の挙動

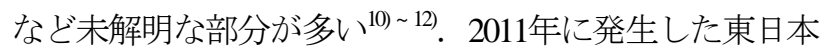
大震災においては，まさにこの縦断方向に大きな地震動 を受けたような被災が発生した ${ }^{13)}$ 14). 主として旧タイプ の3ヒンジ式アーチカルバート (図-2(b)参照) が被災し,

写真-1に示すように, 補強土壁の変状や, ア一チ部材と 基礎コンクリートにカルバート縦断方向に規則的に並ん だ損傷が発生した. 旧タイプは頂部ビームを設置しない など，現行の設計様式より縦断方向の連結が弱い，被災 原因と設計条件の関係を無視できない一方，被災構造物 の大きな特徴は，カルバートの損傷が土被りの小さな領 域や盛土のり面勾配が変化する領域に集中していた ${ }^{13)}$ 点 にあった。

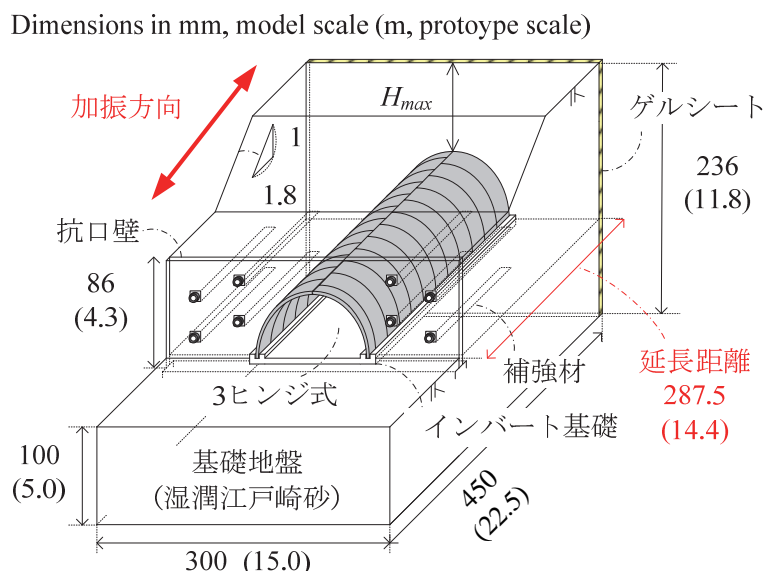

図-3３ヒンジ式を含む盛土模型の概略図

そこで，本研究では，カルバート縦断方向を対象に， 盛土形状がカルバートと盛土の動的相互作用に与える影 響を解明することを目的に，動的遠心模型実験を実施し た．実験においては，3ヒンジ式アーチカルバートを含 む盛土の坑口部をモデル化し，盛土形状をパラメータと して, 縦断方向における地震時応答を確認した.

\section{2. 動的遠心模型実験}

本実験には，京都大学防災研究所所有の遠心力載荷装 置を使用し，遠心力 $50 \mathrm{G}$ 場において岡性土槽 (幅 450 $\mathrm{mm} \times$ 高さ $340 \mathrm{~mm} \times$ 奥行 $300 \mathrm{~mm}$ ) を用いて振動台実験を 実施した．実験模型のモデル化は，振動台実験における 土槽寸法の制約上，盛土部の半断面とした. 図-3に, 実験模型の概略図を示す。実験対象は，5.0 m の基礎地 盤上に，延長距離 $28.8 \mathrm{~m}$ の 3 ヒンジ式アーチカルバート (以下，「3 ヒンジ式」と呼ぶ) を含む盛土が建設された 場合とし，実験では，その半断面である延長距離 $14.4 \mathrm{~m}$ 


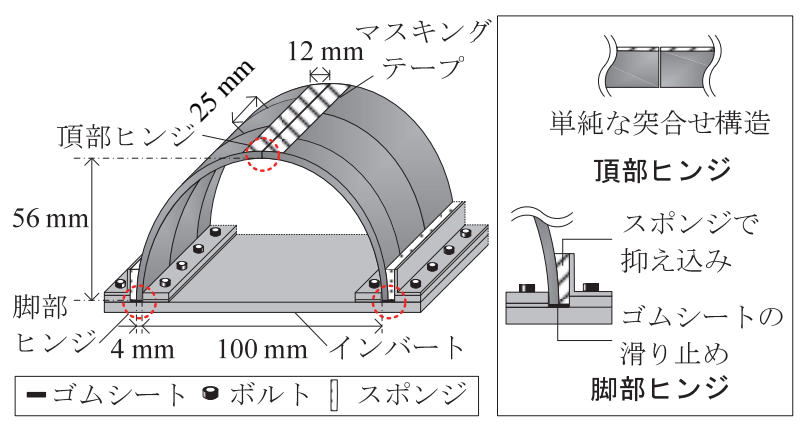

図-4 3ヒンジ式アーチカルバート模型

表-1＼cjkstart実物寸法のRC構造とアルミ合金模型の物性値

\begin{tabular}{llrrr}
\hline 諸元 & - & 単位 & RC構造 & アルミ模型 \\
\hline ヤング率 & $E$ & {$\left[\mathrm{kN} / \mathrm{m}^{2}\right]$} & $2.95 \times 10^{7}$ & $7.06 \times 10^{7}$ \\
\hline せん断岡性 & $G$ & {$\left[\mathrm{kN} / \mathrm{m}^{2}\right]$} & $1.23 \times 10^{7}$ & $2.65 \times 10^{7}$ \\
\hline 奥行 & $a$ & {$[\mathrm{~mm}]$} & 1250 & 1250 \\
\hline 部材厚 & $b$ & {$[\%]$} & 250 & 200 \\
\hline 曲げ岡性 & $E I$ & {$\left[\mathrm{kN} \cdot \mathrm{m}^{2}\right]$} & $4.80 \times 10^{4}$ & $5.88 \times 10^{4}$ \\
\hline 軸岡性 & $E A$ & {$[\mathrm{kN}]$} & $9.22 \times 10^{6}$ & $1.77 \times 10^{7}$ \\
\hline
\end{tabular}

のカルバートを含む盛土をモデル化した。

\section{(1) 3 ヒンジ式アーチカルバートのモデル化}

3 ヒンジ式は，はじめに，キーウェイと呼ばれる凹型 の直接基礎を打設し，その後左右のアーチ部材をキーウ エイにはめ込むことで架設する ${ }^{2)}$. アーチ部材は奥行 $1.0 \sim 2.0 \mathrm{~m}$ 程度であり，奥行方向に連続的に千鳥配置す る. 頂部ヒンジの構造形式は, 図-2 に示したように, ヒンジ部に芯棒を設置した旧タイプ 2)と， 凹凸の突合せ 構造である現在のタイプ 15)がある．新旧どちらのタイプ においても，頂部ヒンジにグラウト工を行う。新タイプ では，最後に頂部ビームと呼ばれるコンクリート梁をア 一千頂部に接合して, 縦断方向に全体的に連結する.

図-4に 3 ヒンジ式模型の概略図を示す。実験模型は, 新タイプの構造的特徵を考慮して作製した。基礎形式は インバート基礎とし，アーチ部材にはアルミ合金を使用 した. 部材の厚みは，実際の RC 構造と曲げ岡性が可能 な限り一致するように調整した結果， $4 \mathrm{~mm}$ とした. プ ロトタイプ、法における RC 構造とアルミ合金模型の諸 元を表-1に整理する.

本実験では，奥行 25 mm (プロトタイプ寸法で奥行 $1.25 \mathrm{~m}$ ) の部材 22 個とその半分の奥行 $12.5 \mathrm{~mm}$ (プロトタ イプ、法で奥行 $0.625 \mathrm{~m}$ ) の部材 2 個の計 24 個のアーチ 部材を左右に 12 個ずつ用いて，千鳥配置とした。模型 における頂部ヒンジの構造は，図-4 に示すように，ア 一千部材の端面同士が接する単純な突合せ条件とした.

アーチ模型は，インバート基礎に設けた型の台座には め込み，スポンジを貼付したアルミ製 L 字アングルを 用いて，アーチの外側から脚部を抑え込むことで固定し ている. なお，アーチ模型の足元には，縦断方向の滑り
を防止するためにゴムシートを貼付した，模型の連結は， 頂部ビームを模擬し，アーチ頂部にマスキングテープを 貼付することでカルバート間を一体的に連結した. カル バート間の目地は，透明のポリプロピレンシートを継ぎ 目を覆うように貼付し, 砂が内部に侵入することを防ぐ よう処置した.

\section{（2）抗口壁のモデル化}

3 ヒンジ式の坑口壁は，補強土壁工法によりほぼ垂直 な壁面が構築されるのが一般的である ${ }^{2)}$. その構造は力 ルバート近傍とそれ以外で異なり (図-1参照), カルバー 卜近傍の壁面は，二枚の大きなコンクリートパネルによ り構築され，分割位置にグラウト工を施すことで一体化 する．それ以外は通常の帯鋼補強土壁工法 ${ }^{16)}$ により構築 される．帯鋼補強土壁工法は，1.5 m × $1.5 \mathrm{~m}$ の十字型を した版状のコンクリートスキンを複数組み合わせて柔な 壁面を構築する工法である.さらに各スキンの背面には， 幅 $60 \mathrm{~mm}$ ，厚さ $5 \mathrm{~mm}$ の補強材が 4 本設置される.

図-5に，坑口壁模型のモデル化と補強材の取り付け 位置を示す，坑口壁模型は，帯工補強土壁工法により構 築されるカルバート近傍の一体的な壁面という特徵をモ デル化した．ただし実際の坑口壁は分割構造であるが, 分割位置にグラウト工を施して一体化される点を考慮し て，坑口壁は一枚のアクリル板でモデル化した．なお， 坑口壁とカルバート模型の接合部には，スポンジテープ を貼付し，隙間から砂が流出しないように処置した。

抗口壁模型は厚さ $5 \mathrm{~mm}$ のアクリル製のパネルを用い， 補強材は幅 $10 \mathrm{~mm}$, 厚さ $0.1 \mathrm{~mm}$ のアルミ製金属板で作 製した．壁面の単位面積当たりのストリップ幅を補強材 密度と定義すると，実際の構造ではおおよそ $60 \mathrm{~mm} \times 4$ / $(1.5 \mathrm{~m} \times 1.5 \mathrm{~m})=107 \mathrm{~mm} / \mathrm{m}^{2}$ となる. 一方，実験模型では， 壁高 $4.3 \mathrm{~m}$ の場合に，プロトタイプで $500 \mathrm{~mm} \times 8 /(15 \mathrm{~m} \times$ $4.3 \mathrm{~m})=62 \mathrm{~mm} / \mathrm{m}^{2}$ となる. 壁面の基礎には厚み $1 \mathrm{~mm} の ア$ ルミ製のアングルを用い，根入れ長はプロトタイプ寸法 で $0.5 \mathrm{~m}$ とした．補強材長は，壁高 $4.3 \mathrm{~m}$ のカルバートを 含まない盛土に対して, 地震時の安全率が 1.2 以上確保 されるよう設計した結果を基に決定した，また，補強材 は壁高と設置位置によらず一律に $5.0 \mathrm{~m}$ として統一した. 補強材の表面には，粘着テープを介して乾燥状態の江 戸崎砂を付着させ，盛士と補強材の間に作用する摩擦力 を発生させるよう処理した. 最適含水比に調整した江戸 崎砂と補強材に対して一面せん断試験を実施した結果, 内部摩擦角 $28.2^{\circ}$, 粘着力 $10.8 \mathrm{kN} / \mathrm{m}^{2}$ となった.

\section{（3）模型地盤と土槽境界}

表-2, 図-6 に模型地盤に用いた江戸崎砂の諸元なら びに締固め特性を示す。ヒンジ式アーチカルバートは, 


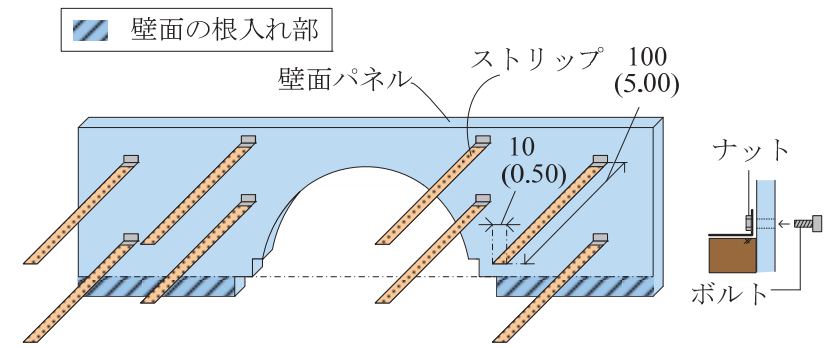

Dimensions in mm, model scale (m, protoype scale)

(a) 壁面模型の構造

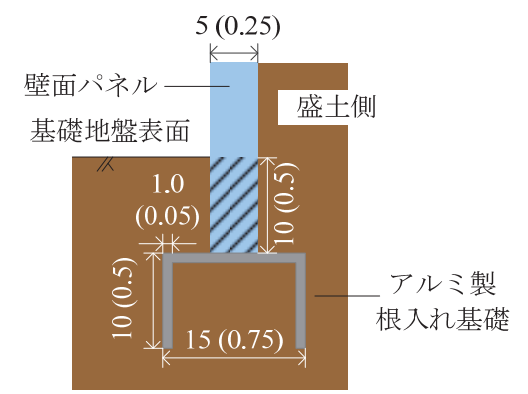

Dimensions in mm, model scale (m, protoype scale)

(b) 根入れ部の構造
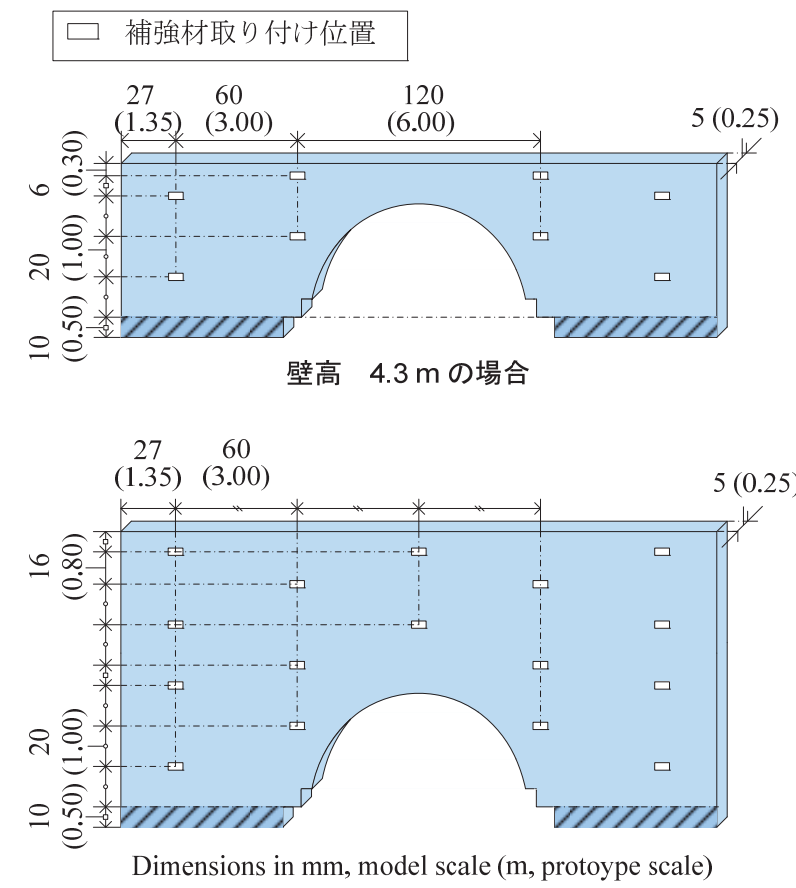

壁高 $8.3 \mathrm{~m}$ の場合

(c) 坑口壁模型の補強材配置

図-5 抗口壁のモデル化

ヒンジ構造により，周辺地盤の変形を引き出すことを設 計の前提としているため, アーチ構造の安定性を確保す るために基礎地盤及び盛土に一定の水準が要求される. そこで，3 ヒンジ式の施工基淮 ${ }^{2)}$ 参考に，模型地盤は 江戸崎湿潤砂を用いて締固め管理により作製した．模型 地盤は基礎地盤と盛土部ともに締固め度 $92.0 \%$ 以，最
表-2 江戸崎砂の諸元

\begin{tabular}{lrrr}
\hline 土粒子密度 & $G_{s}$ & {$\left[\mathrm{~g} / \mathrm{cm}^{3}\right]$} & 2.73 \\
\hline 平均粒径 & $D_{50}$ & {$[\mathrm{~mm}]$} & 0.20 \\
\hline 最適含水比 & $w_{\text {opt }}$ & {$[\%]$} & 17.6 \\
\hline 最大乾燥密度 & $\rho_{\mathrm{dmax}}$ & {$\left[\mathrm{g} / \mathrm{cm}^{3}\right]$} & 1.68 \\
\hline 締固め度 & $D_{c}$ & {$[\%]$} & 92.0 \\
\hline
\end{tabular}

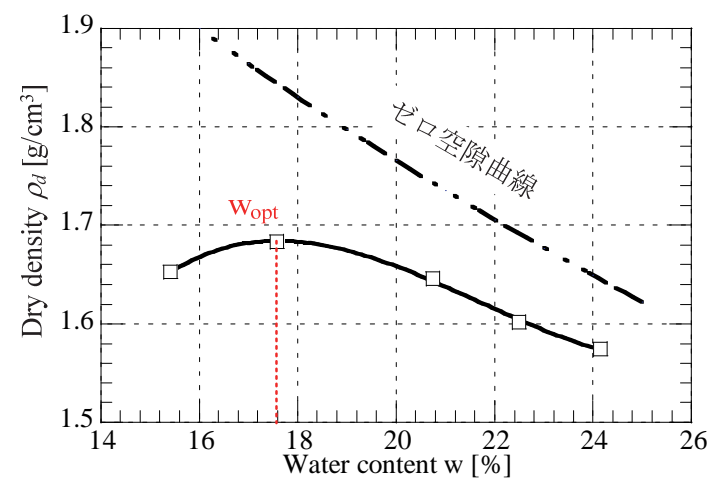

(a) 締固め曲線

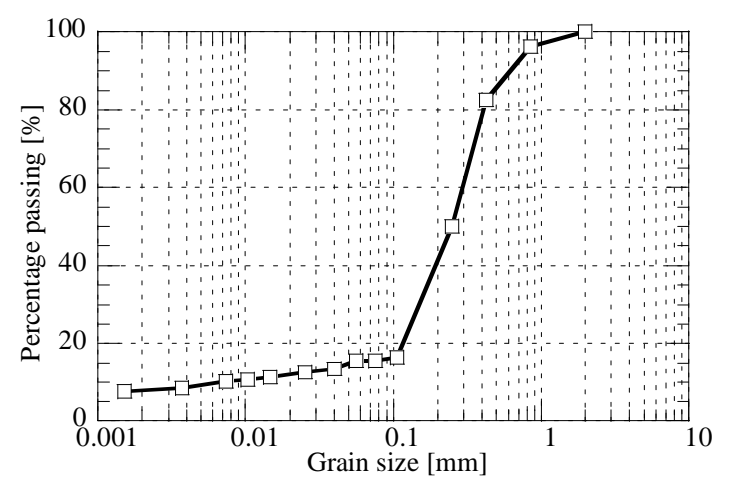

(b) 粒径加積曲線

図-6＼cjkstart江戸崎砂の締固め曲線及び粒径加積曲線

適含水比 $17.62 \%$ で角材により突き固めて作製した.

本実験では盛土の半断面をモデル化するため, 盛土中 央部における土槽との境界面で変位が拘束され，さらに 反射波の影響を強く受けることから，盛土全断面をモデ ル化した場合と異なる挙動を示すことが予想される，そ こで，盛土中央部における土槽側面からの影響を極力緩 和するため, 盛土半断面を対象とした振動台実験 ${ }^{17}$ を参 考にして, 遠心力 $50 \mathrm{G}$ 場において緩衝材の選定実験を 実施した。実験の概略図を図-7に，実験ケースを表-3 に示す．実験では，土槽側壁にゲルシートを貼付し， 1 $\mathrm{Hz} ， 2$ 波の正弦波を最大加速度 $250 \mathrm{gal}$ と $500 \mathrm{gal}$ にそれぞ れ調整して入力した，それぞれの入力波に対する地盤内 の応答加速度を計測した結果，厚さ $2 \mathrm{~mm}, 10 \%$ 圧縮時 の圧縮強度が $0.07 \mathrm{~N} / \mathrm{mm}^{2}$ のゲルシートを用いた場合に, 土槽側壁近傍と土槽中央の地盤の応答加速度の差が最も 小さくなった.この結果から, 緩衝材として上記のゲル シートを加振方向に対して垂直な土槽壁面に貼付するこ 


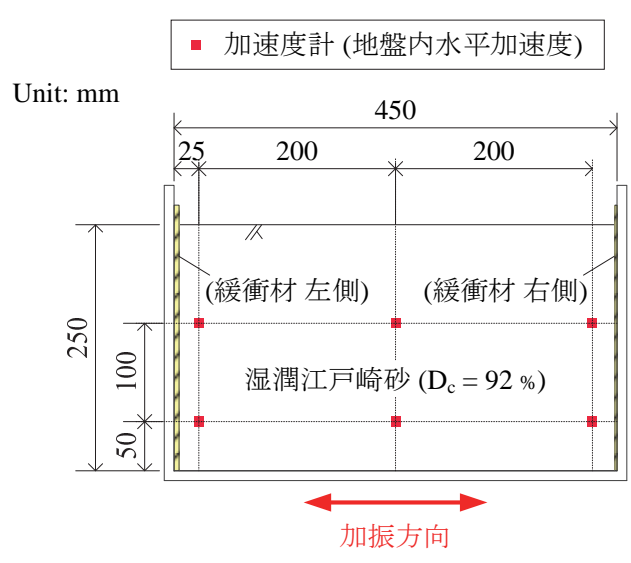

図-7 緩衝材選定実験の概略図

表-3 緩衝材選定実験における実験ケース

\begin{tabular}{|c|c|}
\hline 実験ケース & 緩衝材の種類 [10\%圧縮時の圧縮強度，厚內 \\
\hline \multirow[t]{2}{*}{ Case-1 } & 左側 ＜wide>緩衝材なし \\
\hline & ゲルシート $\left[0.04 \mathrm{~N} / \mathrm{mm}^{2}, t=2 \mathrm{~mm}\right]$ \\
\hline \multirow[t]{2}{*}{ Case-2 } & ゲルシート $\left[0.07 \mathrm{~N} / \mathrm{mm}^{2}, t=2 \mathrm{~mm}\right]$ \\
\hline & ゲルシート $\left[0.07 \mathrm{~N} / \mathrm{mm}^{2}, t=5 \mathrm{~mm}\right]$ \\
\hline
\end{tabular}

ととした.

\section{（4）実験ケース}

盛土形状を実験ケースのパラメータとして設定するに あたり，最小土被り厚，最大土被り厚と盛土のり面勾配

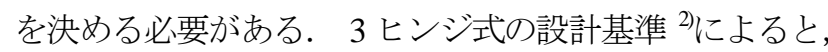
交通荷重を考慮する場合の最小土被りを $1.0 \mathrm{~m}$ と規定し ている. これを参考に，実験ケースにおいても，プロト タイプで $1.0 \mathrm{~m}$ を最小土被りとした. 最大土被り厚に関 しては，実験土槽の制約上プロトタイプで $4.0 \mathrm{~m}$ とした. 盛土のり面勾配に関しては, 道路土工盛土工指針 ${ }^{18}$ に準 じて決定した．同指針によると，盛土高が 0 5.0 mで, 粒度の良い砂で締固める場合, のり面勾配は $1: 1.5 \sim$ $1: 1.8$ としていることから, 本実験ではのり面勾配を $1: 1.8$ とした.

上述した最小土被り，最大土被りおよび盛土のり面勾 配により，4 種類の実験ケースを設定した. 実験ケース を表-4 に示寸．実験ケースは，プロトタイプ寸法で最 小土被りを $1.0 \mathrm{~m}$ で一定に施したケース (Case-1), 抗口 壁から上載盛土法尻までを $5.0 \mathrm{~m}$ としたケース (Case-2), 同じく法尻までの距離を $0.5 \mathrm{~m}$ としたケース (Case-3), 最大土被りを $4.0 \mathrm{~m}$ で一定に施したケース (Case-4) とし た.

\section{（5） 入力波形と計測項目}

入力波形には， $1 \mathrm{~Hz} ， 20$ 波のテーパー付き連続波を用 いた. ここでは, 遠心力 $50 \mathrm{G}$ 場に到達した時点を STEP 0 とし, その後 1 ステップごとにプロトタイプ換算で最
表-4 実験ケース

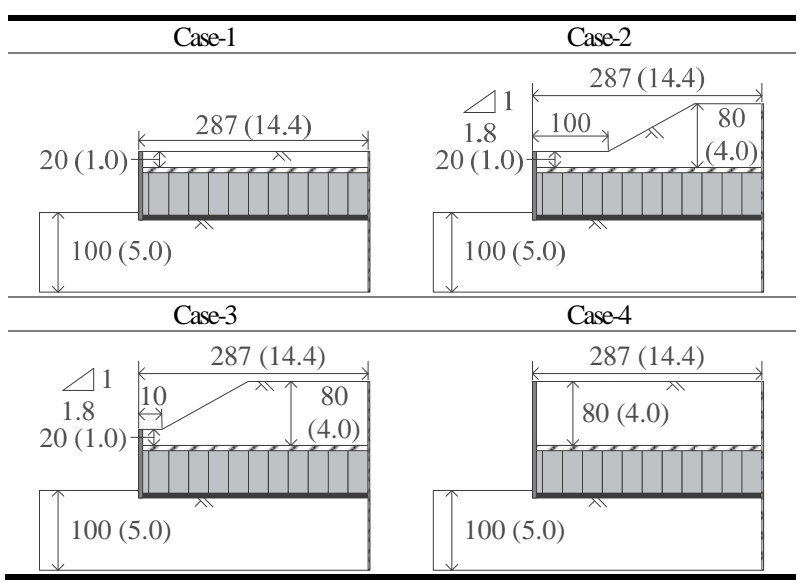

Dimensions in mm, model scale (m, protoype scale)

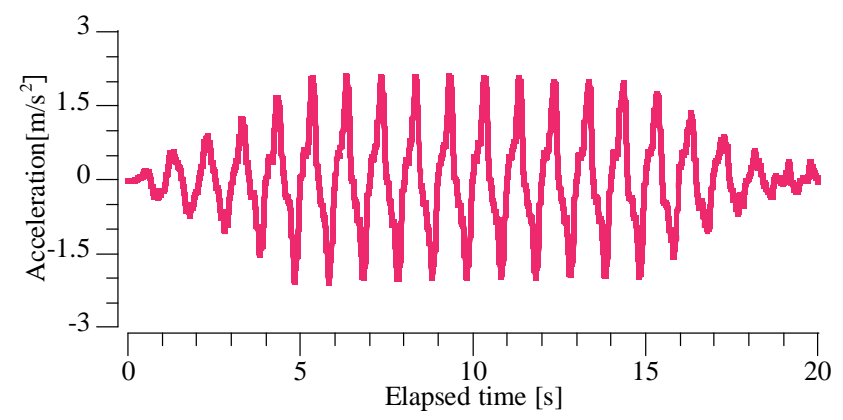

図-8 入力波形

大入力加速度を $0.5 \mathrm{~m} / \mathrm{s}^{2}$ ずつ増やし, 最大入力加速度を $0.5 \sim 5.0 \mathrm{~m} / \mathrm{s}^{2}$ とする計 10 ステップにより加振した. 図-8 には，一例としてSTEP5における入力波形を示寸.

図-9 に計測器の配置と加速度計の呼称を示寸. 加速 度については図中右向きを正, 壁面変位は左向きを正と 定義する. 抗口壁近傍のカルバートをRing 1 , 以後, 順 に Ring $2 \sim 12$ と定義する. 本実験における計測項目は次 に示す通りである.

1） Ring 3,11，地盤，盛士及ひ壁面の応答加速度

2) 壁面の水平変位

3）壁面に作用する水平土圧

\section{3. 実験結果}

\section{(1) 抗口壁の変位量}

図-10には, STEP 1 10 (最大加速度 $0.5 \sim 5.0 \mathrm{~m} / \mathrm{s}^{2}$ ) につ いて, 各加振後における壁面の転倒率, 滑動量, 移動面 積を示す，ここで，図-10(a) より，転倒率は，壁面上端 $\left(\Delta_{1}\right)$ と下端 $\left(\Delta_{2}\right)$ の変位量の差 $\left(\Delta d=\Delta_{1}-\Delta_{2}\right)$ を壁高 $(H)$ で除 した值 $(\Delta d / H)$, 滑動量は壁面下部の水平変位量 $\left(\Delta_{2}\right)$, 移動面積は壁面中央の水平変位量 $\left(\Delta_{m}=\left(\Delta_{1}+\Delta_{2}\right) / 2\right)$ に壁 高 $(H)$ を乗じた值と定義する. 図より, 全加振終了後の 
土木学会論文集C 地圏工学), Vol. 73, No. 4, 429- 441, 2017.

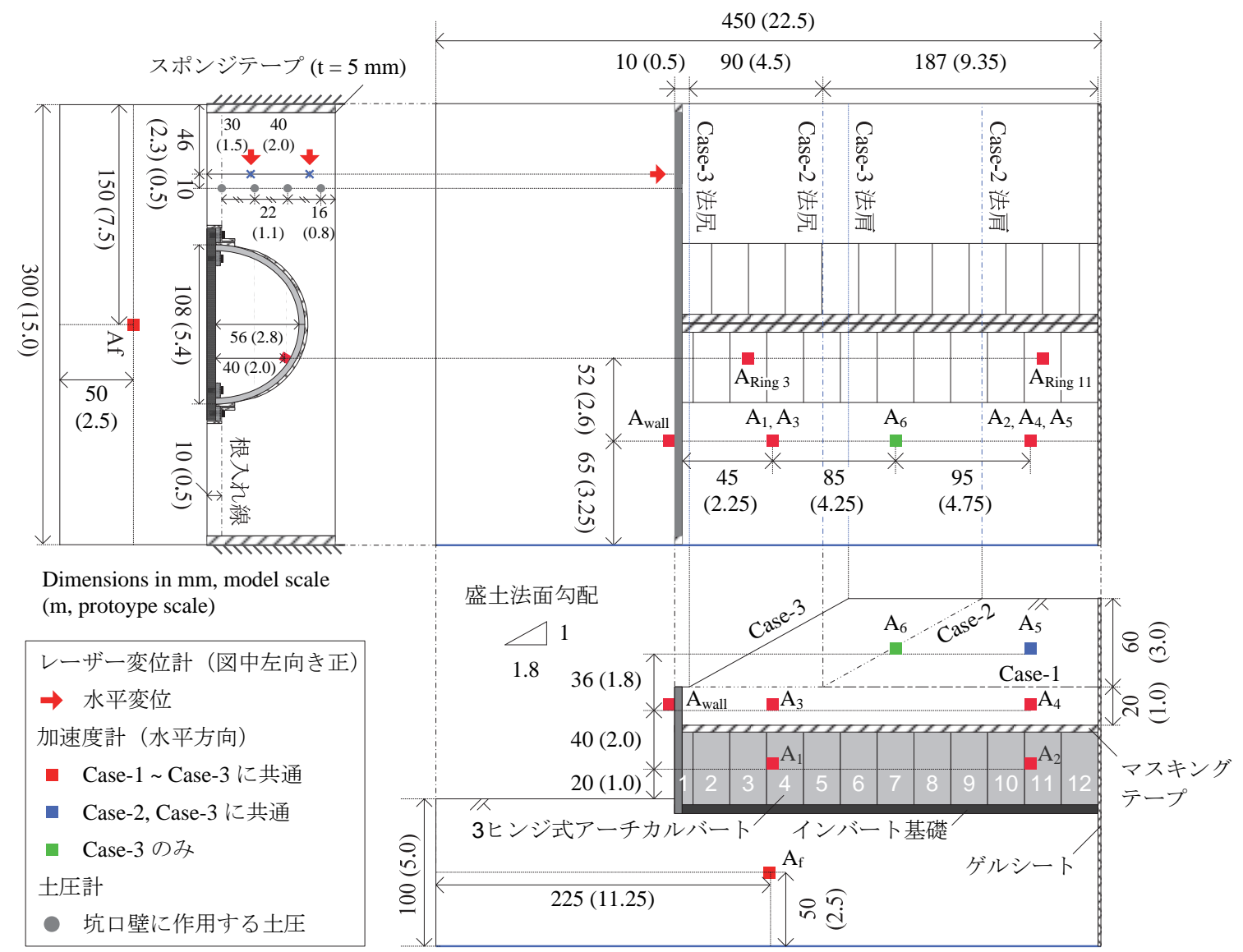

(a) Case-1 Case-3

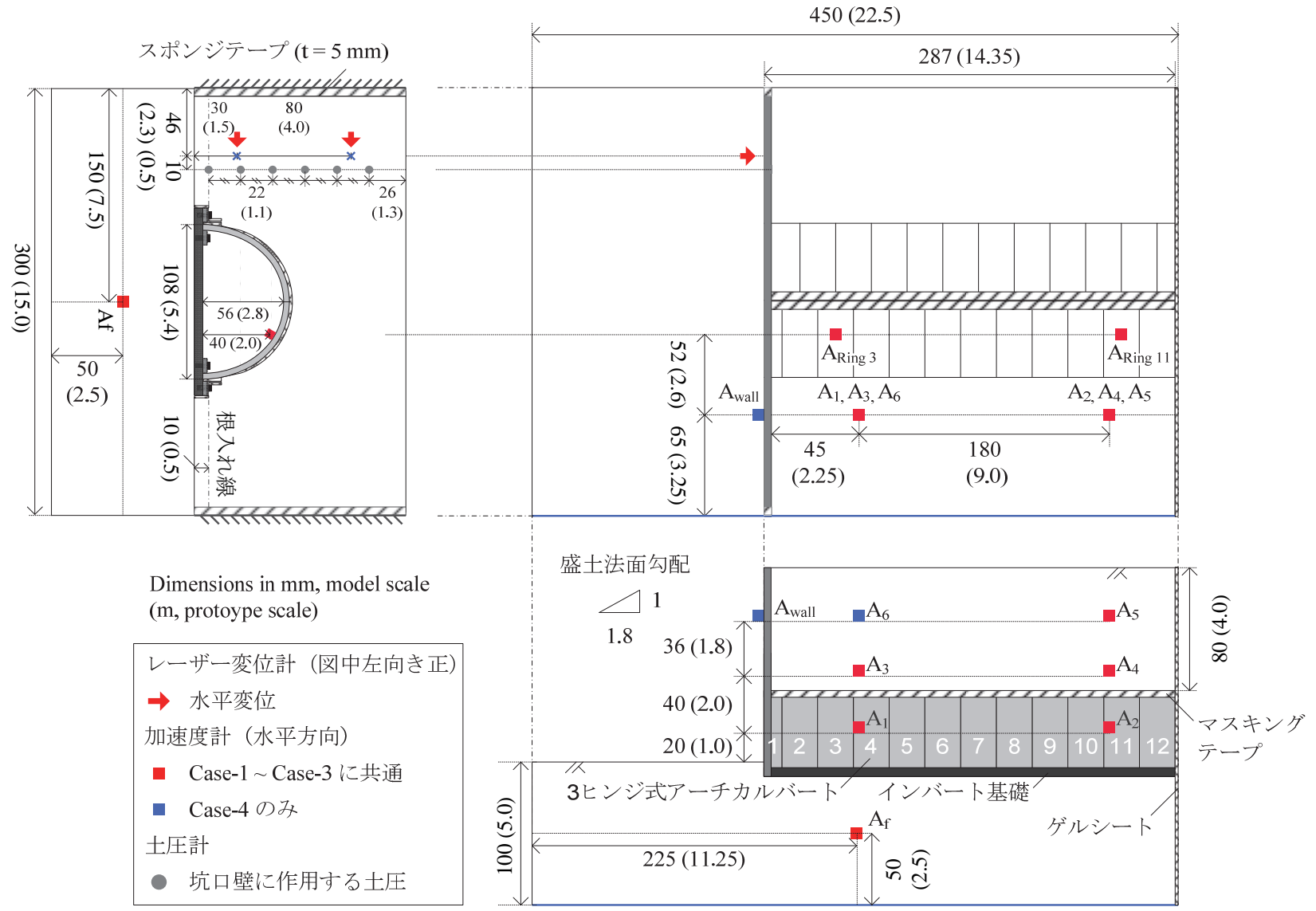

(b) Case-4

図-9 計測器配置 
$\ominus$ Case-1 $\square$ Case-2 $\diamond$ Case-3 $\triangle$ Case-4
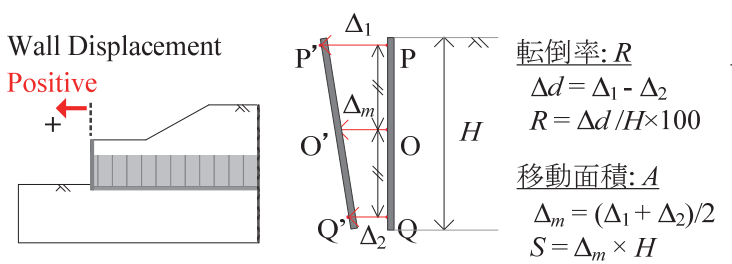

（a）転倒率，滑動量，移動面積の定義

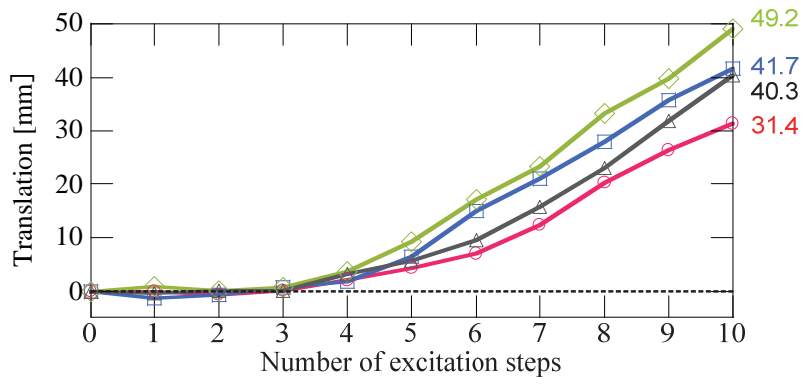

(c) 滑動量

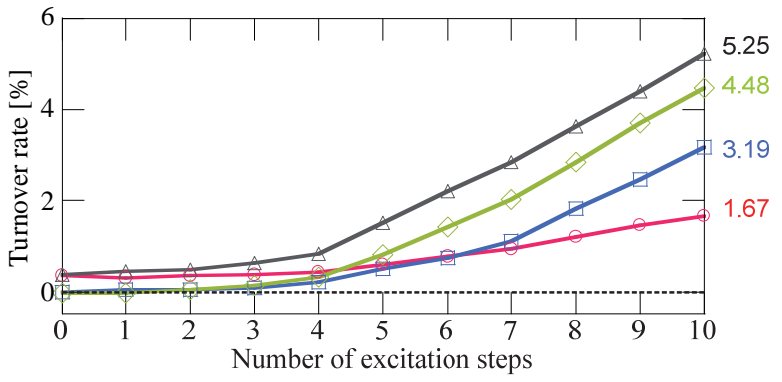

(b) 転倒率

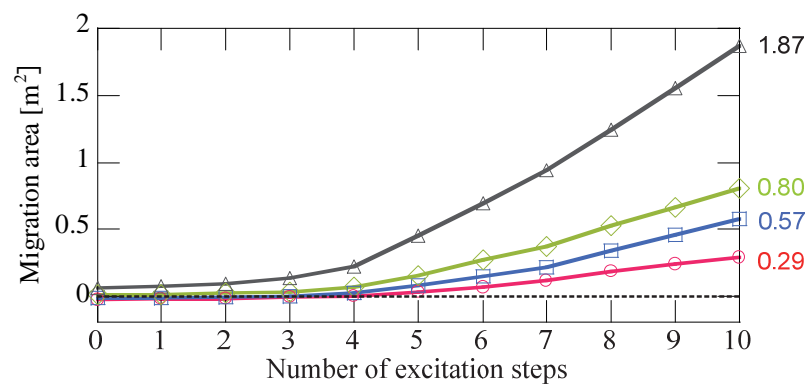

(d) 移動面積

図-10 抗口壁の水平変位量の経時変化

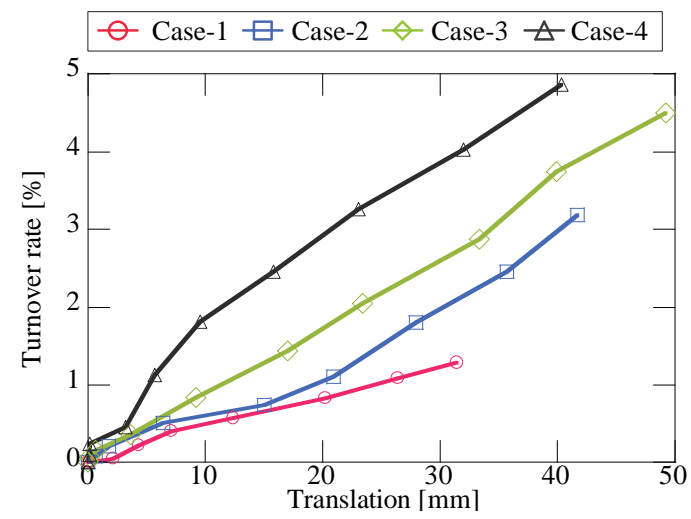

図-11＼cjkstart抗口壁の変位モードの推移

転倒率, 滑動量, 移動面積は, 以下の順に大きくなった.

転倒率 $\quad$ : Case-4 $>$ Case-3 $>$ Case-2 $>$ Case-1

滑動量 $\quad$ : Case- $3>$ Case- $4 \fallingdotseq$ Case- $2>$ Case-1

移動面積 : Case-4 $>$ Case-3 $>$ Case-2 $>$ Case-1

移動面積は，振動に伴う壁面の通過面積であり，盛土の 変形量とみなせる.ここで, 補強材を実験ケース間で統 一したため, Case-4 の変形量は補強材の長さを実施工の 条件に合わせた場合に減少する可能性がある。しかしな がら，ケース間における移動面積の結果から，定性的に は盛土の総重量に比例して, 盛土の変形量も増大する結 果となったといえる.

図-11 には，壁面の転倒率と滑動量の関係について示 す.図-11 より，壁面の転倒率と滑動量の関係は，Case1 から Case-4 の順に，滑動モードよりも転倒モードが顕 著である傾向を示す．つまり，Case-1 と Case-4の関係か

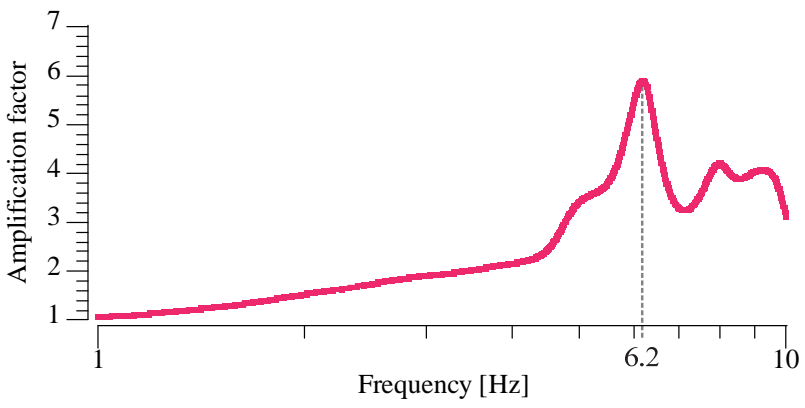

図-12 Ring 3 におけるフーリエスペクトルの増幅率

ら盛土高が高くなると，Case-1,-2,-3の関係から上載盛土 が抗口壁近傍に造成されると，いずれの場合も抗口壁の 変位は転倒モードが顕著になることがわかる.

\section{（2）カルバートと地盤の地震時応答 a) カルバートと地盤の加速度応答}

カルバートが盛土全体の加速度応答に及ぼす影響を評 価するために，カルバートの振動特性を予備実験により 確認した，予備実験においては，本実験条件と同じ基礎 地盤上にカルバート模型を設置し， Ring 3 と基礎地盤に おいて加速度を計測した。実験では，50 G 場において カルバート縦断方向にホワイトノイズを入力した. 図12 に，基礎地盤上の入力に対する Ring 3 のフーリエス ペクトルの増幅率を示す. フーリエスペクトルの算出に は，高速フーリエ変換を用いた．計算データ数は 65536, サンプリング間隔は 0.005 s である. 同図より, Ring 3 の 応答倍率は， $6.2 \mathrm{~Hz}$ でピークを迎えた。 


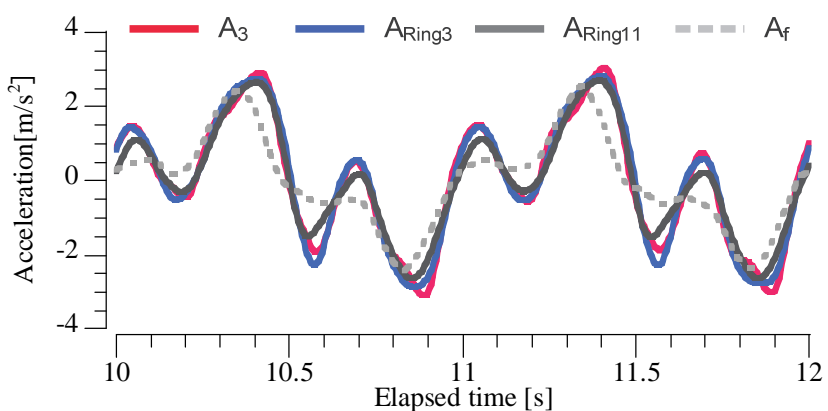

(a) 時間領域表示 Case-1

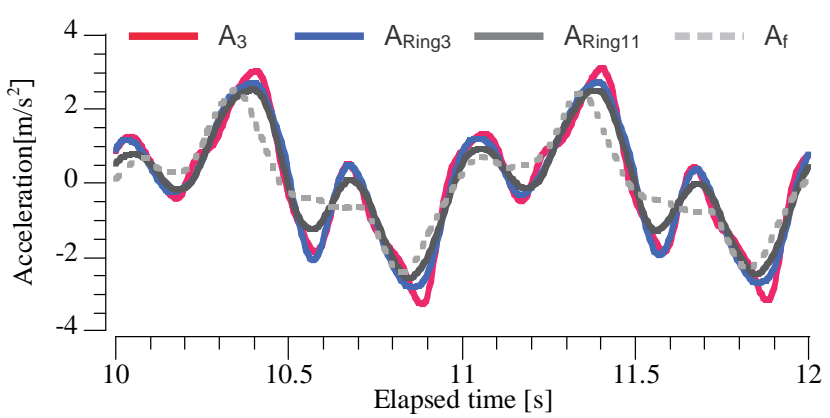

(c) 時間領域表示 Case-2

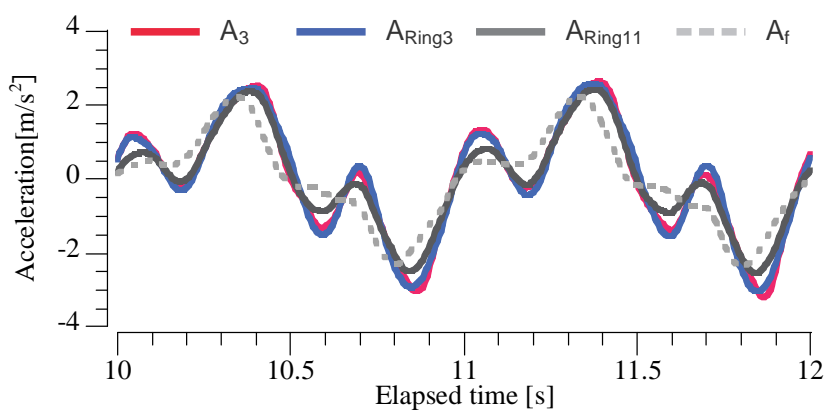

(e) 時間領域表示 Case-3

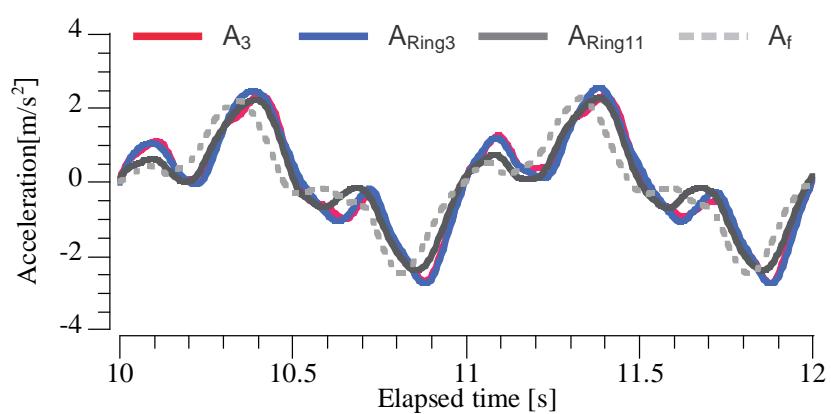

（g）時間領域表示 Case-4

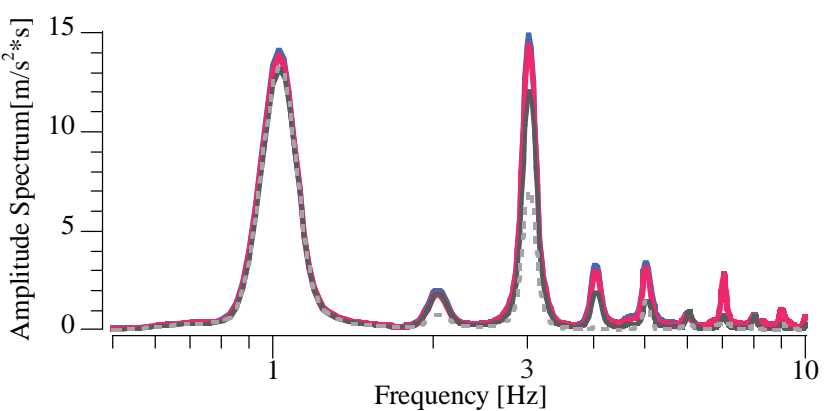

(b) 周波数領域表示 Case-1

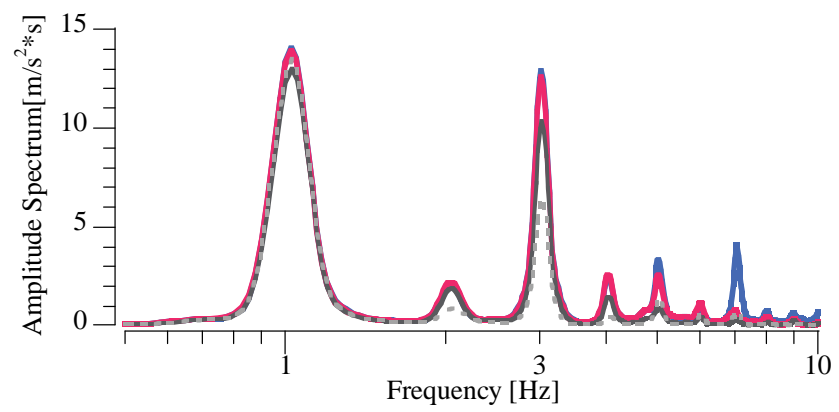

(d) 周波数領域表示 Case-2

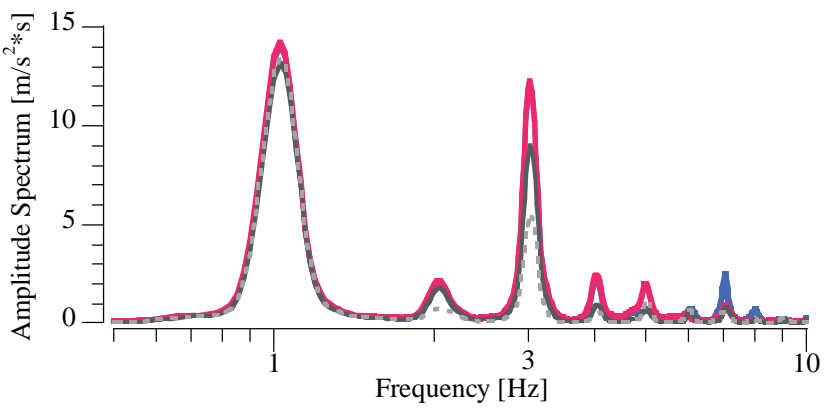

(f) 周波数領域表示 Case-3

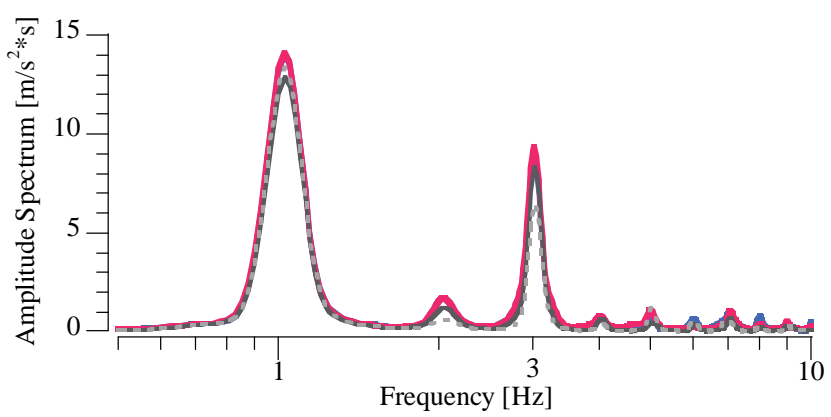

(h) 周波数領域表示 Case-4

図-13 $A_{\text {Ring3, }} A_{\text {Ring11 }}$ と $A_{3}$ の加速度応答（STEP 5: 最大入力加速度 $2.5 \mathrm{~m} / \mathrm{s}^{2}$ )

つぎに，図-13に STEP 5 における Ring $3\left(\mathrm{~A}_{\text {Ring } 3}\right)$, Ring 11 $\left(A_{\text {Ring } 11}\right)$ と Ring 3 近傍の盛土 $A_{3}$, 基礎地盤 $A_{f}$ の加速度応 答について，時間領域表示と周波数領域表示をそれぞれ 示寸. 周波数領域表示には予備実験と同様に高速フーリ エ変換を用いた．計算データ数は 8192, サンプリング 間隔は 0.005 s である. 図より, Case-1 から Case-4におけ る加速度応答の違いは，主に周波数領域において現れて おり, Case-4から Case-1に向からにつれて $3 \mathrm{~Hz}$ 以上のフ
ーリエスペクトルが増大していることがわかる。これは， 図-12 で示したようにカルバートの固有振動数が $6.2 \mathrm{~Hz}$ にあるため, カルバートの応答が入力波の 2 次以降のモ ードである $3 \mathrm{~Hz}, 5 \mathrm{~Hz}, 7 \mathrm{~Hz}$ など $6.2 \mathrm{~Hz}$ 付近の振動数にお いて増幅し，盛土模型の全体積に占めるカルバートの割 合が増加するにしたがって，この増幅の影響が大きく現 れたためと考えられる. 


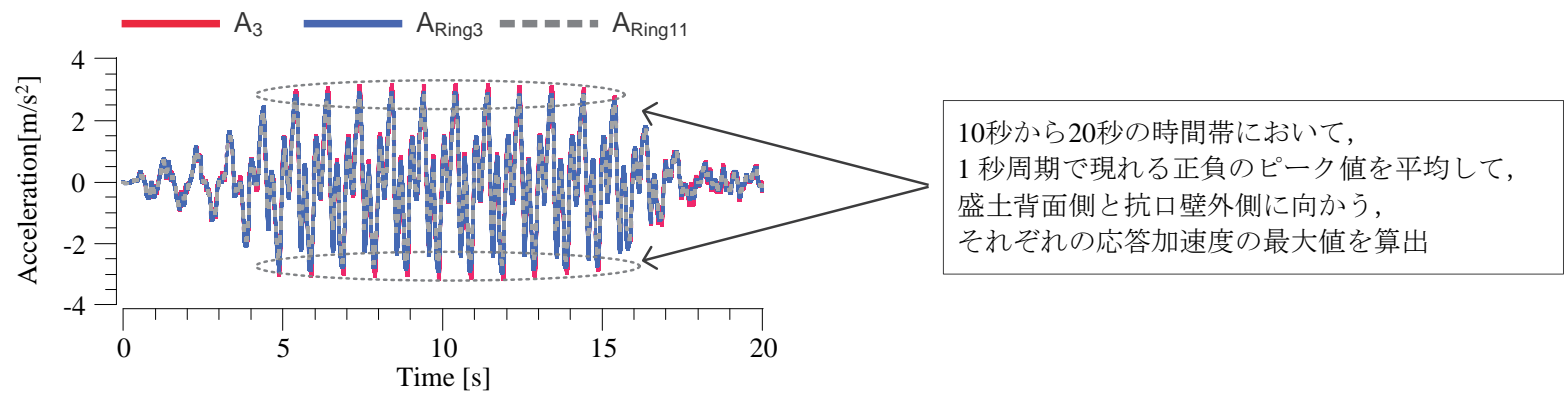

(a) 応答加速度の最大値の算出方法

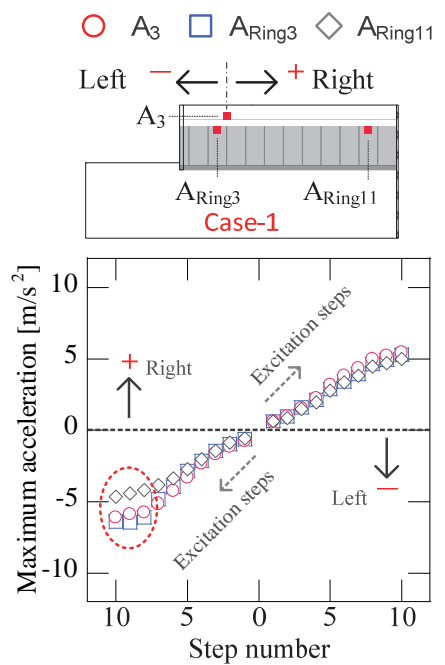

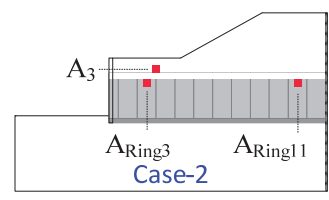

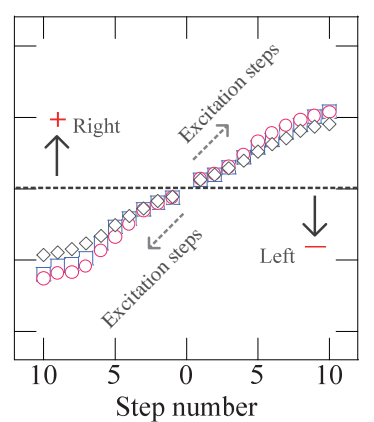

(b) 全加振域における応答加速度の最大值の推移

図-14 応答加速度の最大值の推移と算出方法
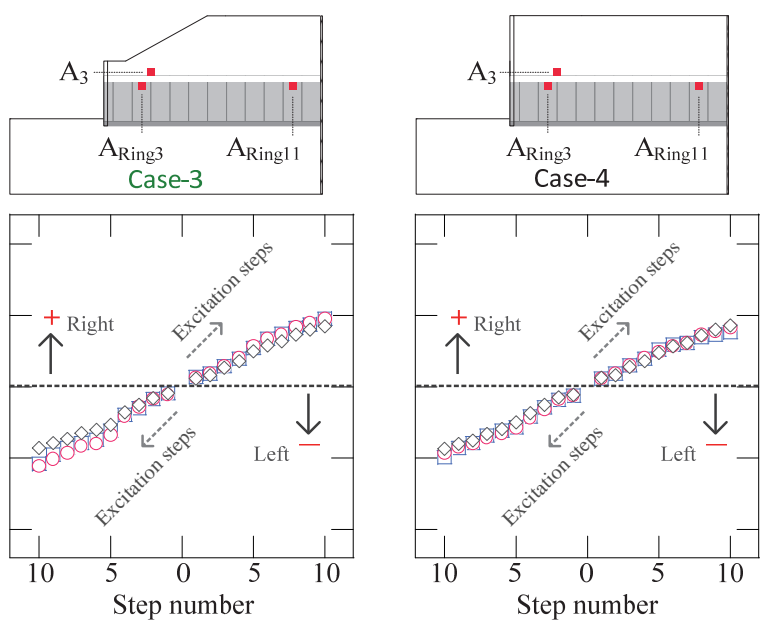

\section{b) カルバートを含む盛土模型の応答加速度の推移}

図-14に，全加振域における $\mathrm{A}_{3}$, Ring 3,11 の応答加速 度の最大值の推移を示す。ここで, 応答加速度の最大值 は，図-14(a)に示寸ように，時刻 $t=10.00 \sim 20.00$ 秒の間に 現れる正負のピーク值をそれぞれの加速度方向に対して 平均して算出した。 なお，図-14(b)には，凡例に示寸右 向きと左向きの応答加速度の最大值をプロットしている。

各ケースの応答加速度に注目すると, Case-1からCase4に向かうにつれて, 応答加速度の増幅が小さくなり, また $\mathrm{A}_{\text {Ring } 3}$ と $\mathrm{A}_{\text {Ring } 11}$ の応答の差が小さくなる。これは土被 りの増大により，カルバートに作用寸る盛土の拘束効果 が大きく働き, 地震時の応答が小さくなるためと考えら れる. 一方, Case-1においては, $A_{\text {Ring } 11}$ と比較して $A_{\text {Ring } 3}$ の応答が大きくなり, さらに, STEP 8, 9, 10において, $\mathrm{A}_{\text {Ring }}{ }_{3}$ の応答值が $\mathrm{A}_{3}$ の值を上回る. この大小関係が変化 した原因は，c)において考察する.

\section{c) カルバートの応答加速度履歴}

図-14に示したように，Case-1における $A_{3}$, Ring 3,11の 応答加速度の大小関係は, STEP 8の時点で変化した。 そ こで, 図-15には, STEP 8について, $t=13.50 \sim 14.48$ 秒に おける, 基礎地盤の応答加速度に対する $\mathrm{A}_{3}, \mathrm{~A}_{\text {Ring }}, \mathrm{A}_{\text {Ring } 11}$ の応答加速度の履歴をそれぞれ示す，同図には，履歴曲
線の開始・終点位置と, 履歴曲線がピークを迎える順番 を併記している.

図より, 各ケースにおける $\mathrm{A}_{3}, \mathrm{~A}_{\text {Ring } 3}, \mathrm{~A}_{\text {Ring 11 }}$ の履歴曲線 の相互関係について, 図中3番のピーク位置(左向きの応 答加速度が最大となる時)に注目して整理する. Case-1で は， $\mathrm{A}_{\text {Ring }}$ の応答が $\mathrm{A}_{3}$ を上回る。一方Case-2とCase-3では, 土被りの増大に応じて $\mathrm{A}_{\text {Ring }}{ }_{3}$ の応答が $\mathrm{A}_{3}$ を下回っており り, $\mathrm{A}_{\text {Ring } 3}$ と $\mathrm{A}_{\text {Ring } 11}$ の応答差は小さい. また, Case-1と比 較して，それぞれの履歴曲線の形状が近づく。さらに Case-4では， $\mathrm{A}_{3}, \mathrm{~A}_{\text {Ring3 } 3}, \mathrm{~A}_{\text {Ring11 }}$ の履歴曲線が殆ど一致する.

$A_{3}, A_{\text {Ring } 3}, A_{\text {Ring } 11}$ の履歴曲線の相互関係がこのように変 化するのは, 図-13，14 で示した通り，盛土形状に応じ て, カルバートを含む盛土の地震時応答が変化するため である. 図-15より, Case-1のように, カルバートの土被 りが1.0 mで一定である場合, 盛土の拘束効果が小さく, カルバートの地震時応答は周辺盛土の応答を卓越し, そ の傾向は最も変形が生じやすい坑口部において顕著であ る. そのため, 坑口部に位置するRing 3と奥に位置する Ring 11における振幅の差が最も大きくなる. Case-2 と Case-3では，Ring 3とRing 11について地震時応答の差が確 認できるが，土被りの増大により，その差が減少する. 一方, Case-4のように, カルバートの土被りが $4.0 \mathrm{~m}$ で一 


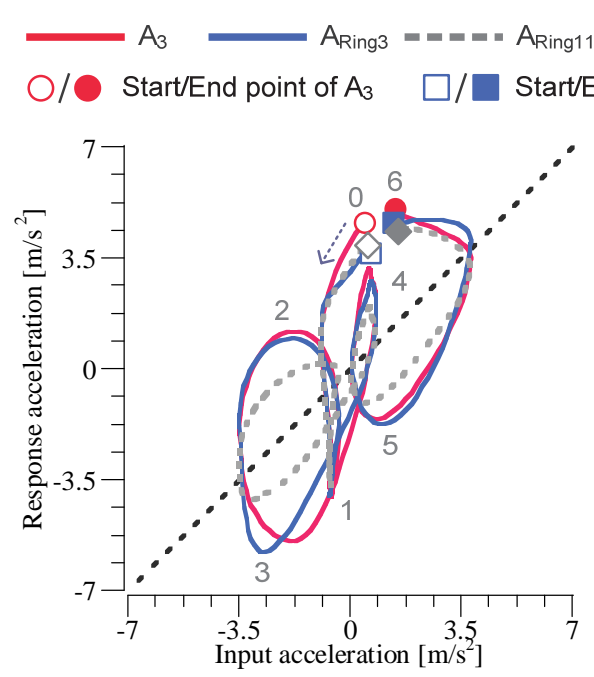

(a) Case-1

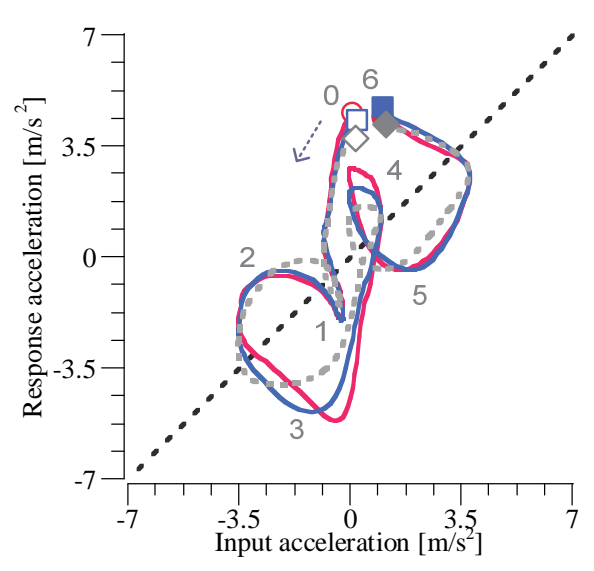

(c) Case-3 $\diamond / \diamond$ Start/End point of Ring 11

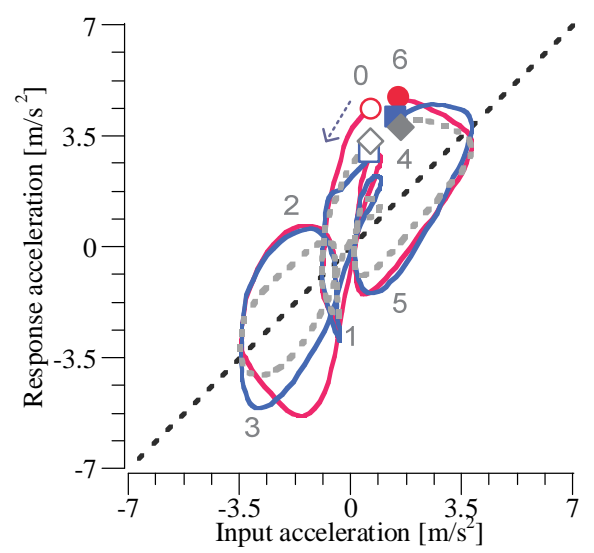

(b) Case-2

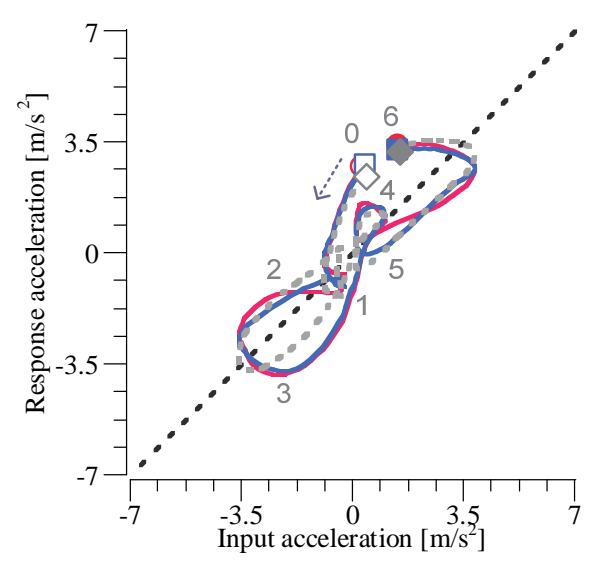

(d) Case-4

図-15 $\mathrm{A}_{\text {Ring3, }} \mathrm{A}_{\text {Ring11 }}$ と $\mathrm{A}_{3}$ の応答加速度履歴（STEP 8: 最大入力加速度 $4.0 \mathrm{~m} / \mathrm{s}^{2}$ )

定である場合，盛土の拘束効果が大きくなり，カルバー 卜は周辺盛土と一体的に応答する。

\section{d）上載盛土と坑口部の地震時応答の関係}

図-16に，1 Hzの連続波を入力地震動とした本実験に おいて, Case-1 Case-4の加速度応答から推測されるカル バートを含む盛土の地震時モードと上載盛土の拘束効果 の関係を示す．図より，土被りが小さい場合，最も盛土 の拘束効果が小さくなる坑口部でカルバートの応答が大 きく増幅し, 周辺地盤の応答を卓越すると考えられる. 土被りが大きい場合, 盛土の拘束効果も大きいため, カ ルバートは周辺地盤の応答に追従し, 坑口部における応 答の増幅が抑制されると考えられる.ただし，図-10,

11 で示した通り，土被りが大きくなるにつれて，盛土 の総重量の増大に伴って, カルバート縦断方向の地震時 における坑口壁の変位量が増加することに留意する必要 がある。

\section{(3) 加振後の盛土模型の状態}

写真-2 に, 加振後の盛土地表面の状態を示す. 写真 には，抗口壁近傍のクラックの発生状態を赤線で示して いる. 写真より, Case-1 から Case-3に共通して, 被りの 小さい坑口部付近で縦断方向のひび割れが発生している. このひび割れは, カルバート頂部の位置に, カルバート 軸方向に沿って発生していることから, カルバート横断 方向の引張力が働いたものと考えられる. 実験において は，カルバート周辺の盛土部において圧縮変形量が大き くなり, カルバート直上の地表面で横断方向の引張力が 作用し，軸方向のひび割れが発生したと考えられる.

Case-4 では, 補強材の敷設位置において, カルバート 縦断方向にクラックが発生している. さらに, 盛土中央 部では，写真において水平方向 (カルバート横断方向)に 大きくクラックが発生している. これは, 盛土天端の変 位が大きくなった結果, 盛土天端に強い引張力が作用し, 水平方向に大きなクラックが発生したと考えられる. 土 被りの増大は, カルバート縦断方向の地震時において, 
カルバートの応答加速度 ー カルバート直上の盛土の応答加速度
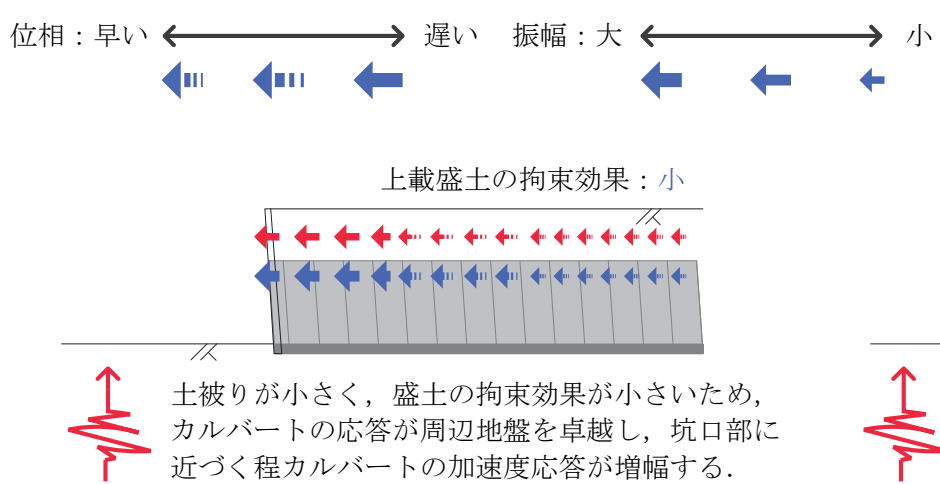

カルバート縱断方向の地震動

カルバート縱断方向の地震動

(a) 上載盛土の拘束効果が小さい場合

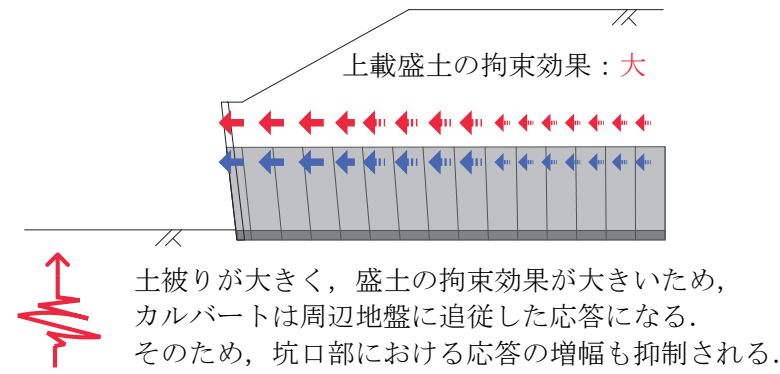

(b) 上載盛土の拘束効果が大きい場合

図-16 1 Hzの入力に対するカルルバートを含む盛土のカルバート縦断方向の地震時応答

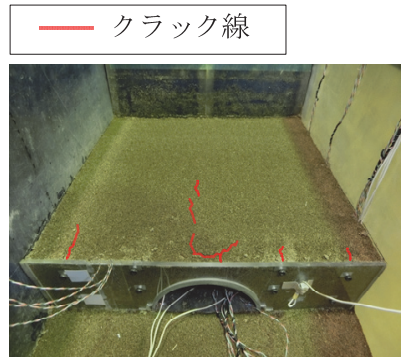

(a) Case-1

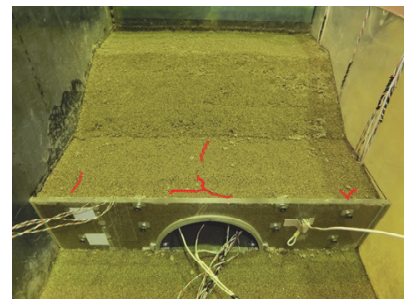

(b) Case-2

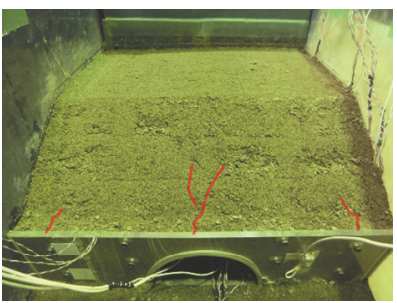

(c) Case-3

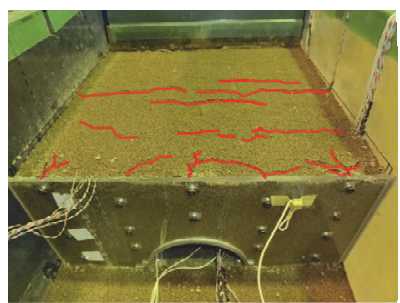

(d) Case-4

写真-2＼cjkstart加振後の盛土地表面の状態

カルバートの応答を抑制する観点からは有効だか，盛土 地表面の変位が大きくなることに留意する必要がある.

写真-3, 写真-4 に，各ケースにおける加振前後の坑口 部とヒンジ部の状態を示す．本実験においては，頂部ヒ ンジを単純な突合せ構造としたため，実施工における凹 凸の突合せ構造よりもアーチは崩壊に至り易い条件だと 考えられる.しかし，写真より，盛土が大きく変形して も，被災に見られたように頂部ヒンジがずれ落ちること はなかった。

\section{4. まとめ}

本研究では，3ヒンジ式を含む盛土模型に対して，1 $\mathrm{Hz} ， 20$ 波の正弦波を，最大入力加速度を $0.5 \mathrm{~m} / \mathrm{s}^{2}$ ずつ段階 的に増大させて計 10 回入力した．本実験で得られた，盛 土形状がカルバートと盛土の動的相互作用に与える影響 に関する知見は以下の通りである.

1) カルバート縦断方向の地震動に伴う盛土の変形量 は，概ね盛土の総重量に比例する，その変位モ一 ドは，上載盛土の形状に依存し，盛土高が大きく なるほど，また，上載盛土の法尻と抗口壁の距離
が短いほど，坑口壁は転倒モードに近づく。

2) カルバート縦断方向の地震時応答は，盛土の拘束 効果に大きく影響を受ける. カルバートの土被り が小さい場合，最も盛土の拘束効果が小さくなる 坑口部で，カルバートの応答が大きく増幅し周辺 地盤の応答を卓越する. カルバートの土被りが大 きい場合，盛土の拘束効果も大きいため，カルバ 一トは周辺地盤に追従した応答になり，坑口部に おける応答の増幅も抑制される.

3）土被りが縦断方向に一定に大きく施される場合， 縦断方向の地震時において，盛土天端の変位が大 きくなったことが原因と考えられる地盤のクラッ クが発生した。土被りの増大は，縦断方向の地震 時において，カルバートの応答を抑制する観点か らは有効だか，盛土地表面の変位が大きくなるこ とに留意する必要がある。

4) 最小土被りを $1.0 \mathrm{~m}$ 以上施し，頂部ヒンジを単純な 突合せ構造とした本実験の範囲内では，縦断方向 の繰り返しの地震動により盛土が大きく変形して も，頂部ヒンジがずれ落ちることはなかった。

ヒンジ式アーチカルバートの耐震性は，これまでカル バート縦横断方向の地震動それぞれに対して確認されて 

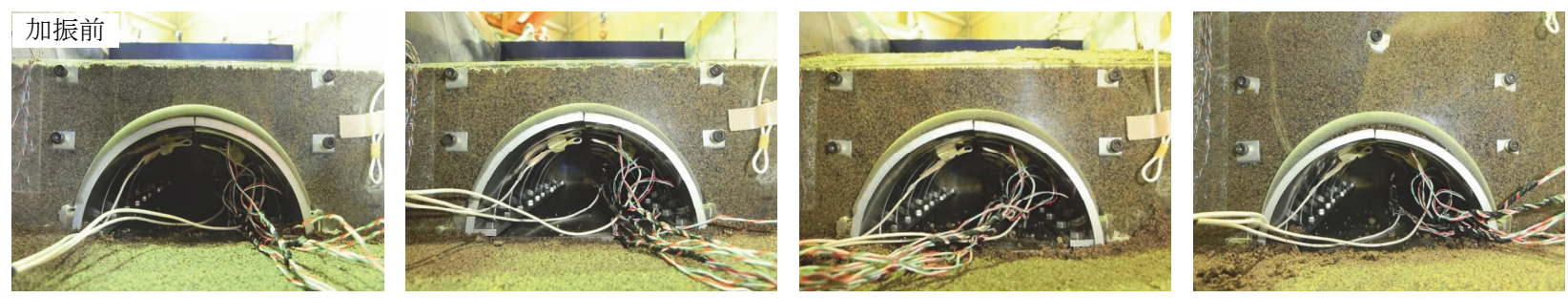

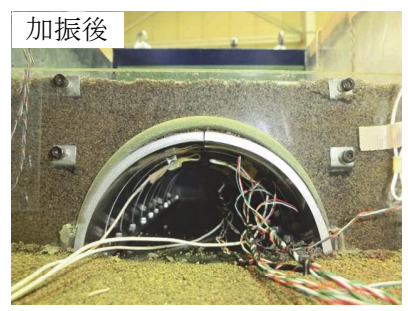

(a) Case-1

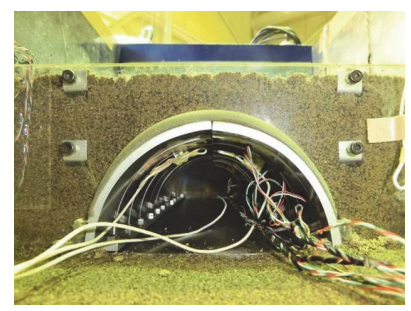

(b) Case-2

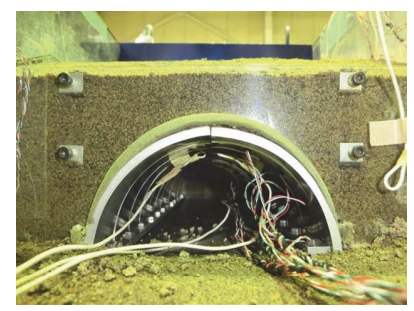

(c) Case-3

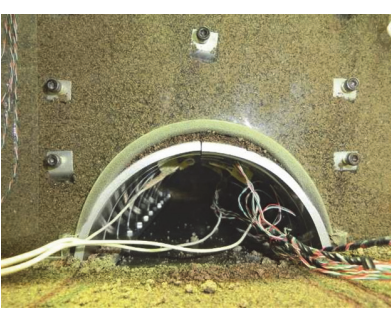

(d) Case-4

写真-3 加振前後の坑口部の状態

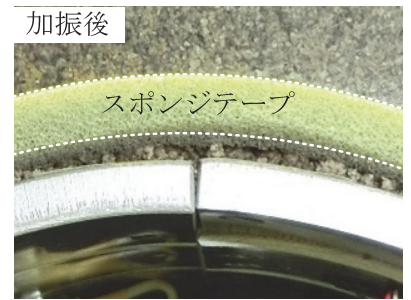

(a) Case-1

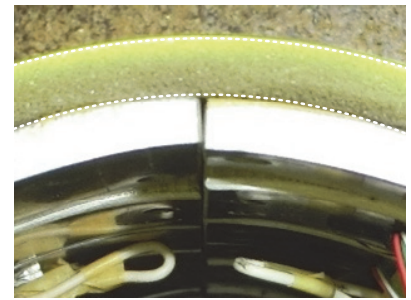

(b) Case-2

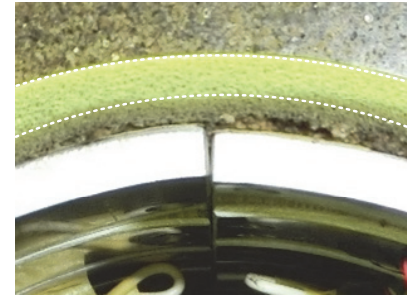

(c) Case-3

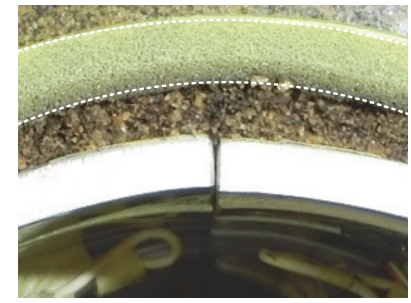

(d) Case-4

写真-4 加振後のヒンジ部の状態

きた 5) 8), 10) 12). 既往の研究と本研究成果を踏まえると, ヒンジ式アーチカルバートは良好な基礎地盤, 過度な偏 荷重が作用しないなど，設計に即した条件では，大きな 地震動においても，カルバート構造が崩壊するには至ら なかった。それにも関わらず，東日本大震災で構造上致 命的な被災が報告された ${ }^{13)}{ }^{14}$ 事実を鑑みると，地震時に おいてアーチ機構上不利に働く要因の把握と旧タイプの 既設構造物への対策工の提案が急務である。そのために， アーチの安定性に不利に働く施工条件 (大きな縦断勾配 や道路盛土本線に対して斜めに設置された斜角のつく構 造) や，ねじれ方向からの地震動の入射といった条件下 で，アーチカルバートを含む盛土の三次元的な地震時挙 動を引き続き確認する必要がある.

謝辞：本研究の一部は，公益信託NEXCO関係会社高速 道路防災対策等に関する支援基金平成28年度高速道路の 防災対策への助成を受けたものである.

\section{参考文献}

1) モジュラーチ工法協会 : Modularch 技術マニュアル, 財団法人 地域地盤環境研究所, 2008 .

2) 財団法人 先端建設技術センター「テクスパン工法設 計施工マニュアル検討委員会」：テクスパン工法設
計施工マニュアル(案), 1998.

3) 入江伸明, 伊藤和也, 高橋章浩, 日下部治 : 3 ヒンジ トンネルの地震時挙動に関する遠心実験, 第 37 回地 盤工学研究発表会, pp. 1779-1780, 2002.

4) Byrne, P. M., Anderson, D. L. and Jitno, H. : Seismic analysis of large buried culvert structures, Transportation Research Record, Vol. 1541, pp. 133-139, 1994.

5) 熊田哲規，高橋裕輔，北林孝顕，堀田三成，大井純， 小泉淳 : テクスパン工法を用いたトンネルの模型振 動実験(その 1)一テクスパン工法および模型振動実験 の概要について一, 土木学会第 50 回年次学術講演会 講演集，III-556, pp. 1112-1113, 1995.

6) 澤村康生，石原央之，岸田潔，木村亮：強震応答実 験による 3 ヒンジプレキャストアーチカルバートの 損傷形態の把握，土木学会論文集 C, Vol. 72, No. 2, pp. 62-73, 2016. doi.org/10.2208/jscejge.72.62

7) Sawamura, Y., Ishihara, H., Kishida, K. and Kimura, M.: Experimental study on damage morphology and critical state of three-hinge precast arch culvert through shaking table tests, Procedia Engineering, Advances in Transportation Geotechnics III, Vol. 143, pp. 522-529, 2016. (dx.doi. org/10.1016/j.proeng.2016.06.066)

8) Sawamura, Y., Kishida, K. and Kimura, M.: Experimental study on seismic resistance of a two-hinge precast arch culvert using strong earthquake response simulator, Japanese Geotechnical Society Special Publication, The 15th Asian Regional Conference on Soil Mechanics and Geotechnical Engineering, Vol. 2, No. 48, pp. 1684-1687, 
2015. (doi: 10.3208/jgssp.JPN-103)

9)常田賢一，小田和広，鍋島康之，江川裕輔：新潟県 中越地震における道路施設の被害水準と道路機能の 特性, 土木学会地震工学論文集, Vol. 28, No. 009, pp. 1-9, 2005. doi.org/10.11532/proee2005a.28.9

10）澤村康生，荒居旅人，岸田潔，木村亮：壁面工を有 する盛土内に設置されたアーチカルバートにおける 縦断方向の地震時挙動に関する遠心模型実験，地盤 工学ジャーナル, Vol. 9, No. 1, pp. 41-57, 2014.3. (doi.org/10.3208/jgs.9.41)

11) Sawamura, Y., Kishida, K. and Kimura, M.: Dynamic centrifuge model tests on culvert embankment with perpendicular wall in culvert longitudinal direction, Proc. of the 8th International Conference on Physical Modelling in Geotechnics, pp. 883-889, Perth, 2014.1. (doi: 10.1201/ b16200-123)

12) 宮﨑祐輔, 澤村康生, 岸田潔, 木村亮 : 2 ヒンジプレ キャストアーチカルバートを含む盛土におけるカル バートの連結様式を考慮した縦断方向の動的挙動の 評価, 地盤工学ジャーナル, Vol. 10, No. 4, pp. 517-
529, 2015. doi.org/10.3208/jgs.10.517

13) 安部哲夫, 中村雅範：高速道路における大型のプレ キャスト部材を用いたカルバートの活用と適用上の 留意点, 基礎工, Vol. 42, No. 4, pp. 8-11, 2014.

14) 小島均, 佐藤光男：プレキャスト・アーチカルバー 卜の被災, 論文番号 400.3, 第 29 回日本道路会議, 2011.

15) 瀬戸英俊, 大谷義則, 酒井茂賀 : テクスパン工法の 概要と施工事例, 基礎工, Vol. 42, No. 4, pp. 52-55, 2014.

16) 財団法人 土木研究センター : 補強土(テールアルメ) 工法 設計・施工マニュアル 第 4 回改訂版, 2014.

17) 清田三四郎, 森野達也, 米沢豊司, 丸山修, 小島謙 一，坂本寛章：パイルスラブ式盛土の模型振動台実 験一盛土補強材の効果一, 土木学会第 65 回年次学術 講演会, pp. 729-730,2010.

18) 社団法人 日本道路協会 : 道路土工 盛土工指針(平成 22 年度版), 丸善出版, 2011.

(2016. 11. 25 受付)

\title{
DYNAMIC CENTRIFUGE MODEL TESTS ON SEISMIC PERFORMANCE IN CULVERT LONGITUDINAL DIRECTION OF HINGE-TYPE ARCH CULVERTS DUE TO PATTERNS OF EMBANKMENT SHAPE
}

\author{
Yuusuke MIYAZAKI, Yasuo SAWAMURA, Kiyoshi KISHIDA \\ and Makoto KIMURA
}

At the 2011 off the Pacific coast of Tohoku earthquake, hinge-type arch culverts experienced the large damage which led to loose the transport availability for the first time. The resultant disaster seems to be closely related to the inertial force in the culvert longitudinal direction. These damaged culverts had one point in common, namely, the small soil cover of the culverts or the embankment slope began very near the mouth wall. Therefore, the aim of this study is to clarify the influence of the embankment shape on the seismic behavior of precast arch culverts in the culvert longitudinal direction. We performed dynamic centrifuge tests on an embankment model including precast arch culverts with the change of embankment shape patterns. As a result we found that in the case of the culverts with small soil cover, the seismic behaviour of the culverts near the mouth with the smallest constraining effect of embankment get to be amplified largely and exceeds that of the surrounding embankment, and that in the case of the culverts with large soil cover, the seismic behaviour of the surrounding embankment strongly binds that of the culverts near the mouth, which leads to the united response between the culverts near the mouth and the surrounding embankment. 